\title{
SOCIALLY RESPONSIBLE MARKETING IN THE "NEW NORMAL"
}

\author{
Marina Guzovski ${ }^{1}$
}

DOI: https://doi.org/10.31410/LIMEN.2020.285

\begin{abstract}
Given the fact that we are in a time of uncertainty, when we cannot predict how a coronavirus-induced pandemic will affect community life, socially responsible behaviour as well as the impact of socially responsible marketing come to the fore in particular. The goal of socially responsible marketing is to educate and take actions that will positively affect the change of behaviour, and all participants from business entities to individuals must be aware of their responsible behaviour towards themselves and others in order to improve well-being and benefit the society we live in.

The paper presents models of socially responsible marketing communication in the "new normal" as well as their impact on raising awareness of responsible behaviour and the adoption of new habits among consumers.
\end{abstract}

Keywords: Responsible behaviour, Social responsibility, Marketing communication, "New normal".

\section{INTRODUCTION}

$t$ the beginning of the year, no one could have imagined that a pandemic of COVID-
19 disease caused by coronavirus would completely change the way of doing business,
as well as the lifestyle people were used to. We followed what was happening in the world and thought it was happening to someone else so it will bypass us. But then everything stopped one day, people started working from home, business was being done online, and the digital environment quickly became "the new normal" for work, studying, socializing, business, etc. The whole situation caused changes in all business segments as well as it affected the change in our lifestyle. The influence of socially responsible marketing on the development of awareness of socially responsible behaviour in the "new normal" in these circumstances is especially evident in all forms of marketing communication aimed at education and action that will positively affect behaviour change of all stakeholders and adopt some new habits to improve the quality of life in "the new normal". This is one of the most difficult tasks of socially responsible marketing - changing and creating new habits because people do not like to change their habits when they already have built attitudes and lifestyle, and behaviour change requires a great sacrifice in terms of the usual lifestyle. And no matter how much the importance of responsible behaviour is pointed out, no matter how much the dangers of irresponsible behaviour are pointed out, there will always be those who are against that, those who will go against everyone and endanger themselves, and thus others.

The paper discusses the communication models of socially responsible marketing in the "new normal" through marketing communication, and the research shows how much the messages of socially responsible marketing have influenced the raising of awareness of responsible behaviour, creating some new habits and lifestyle changes.

1 Libertas International University, Trg J. F. Kennedy 6b, Zagreb, Croatia 


\section{CHARACTERISTICS OF MARKETING COMMUNICATION}

Social marketing is a discipline that improves life in the community (Kotler, Lee, 2007, p. 189), and implies the application of marketing in the process of realization of social goals which as a basic or derived starting point do not prioritize profit, but meets the needs of society, i.e. social character (Meler, 1994, p.42). Ultimately, the goal of social marketing is to influence the behaviour and development of individuals and targeted groups to benefit them, which are related to health, education, general social well-being and more (Guzovski, 2018). In communication with the society stakeholders through social marketing, we try to change the disbelief to belief, change the opinion, attitude, values and everything that has an impact on behaviour and will ultimately result in a positive change in behaviour for the benefit of society as a whole. This is exactly the most difficult marketing task because people are asked: to give up pleasure, to get out of their comfort zone, to give up aesthetics, to change their routine, to resist the pressure of the environment, to spend more time and money, to hear bad news, to establish new habits, to give up old habits, to change a comfortable lifestyle, risk rejection, learn new skills and more. It is a real problem and the big difference is that one cannot give, show or promise the user something tangible in return - especially in the short term (Kotler, Lee, 2007, pp. 190 -191).

The coronavirus disease pandemic COVID-19 affects not only individuals and does not require responsible behaviour only from individuals but also from business entities, and also includes all business segments. The usual ways of doing business have changed, more and more people are doing business online and business is being transferred to the digital environment, which will leave consequences and affect the business in the future as well. Developing a digital marketing strategy to attract customers in the online market, gaining market share, positioning, increasing brand value, meeting customers and determining segments according to the principles of privacy, measurability, availability, profitability and operability, achieving business goals and shaping marketing mix strategy with planned activities, goals and ways of advertising become an indispensable part of marketing planning (Smoljić, Guzovski, Rudančić, 2020, p. 427). Marketing communication in a "new way" more than ever must be creative and innovative, appropriate to the situation, flexible but customer-oriented, authentic and optimistic. The emphasis of communication is on security and responsibility for both customers and employees with the application of all measures and recommendations in force in the fight against the virus: from the use of masks, social distance, number of customers in stores, contactless payment options, business through web store and other. Communication with consumers is realized through social networks and other forms of communication in the digital environment, and is aimed at targeted advertising, connecting with others, but also connecting companies and products as a brand. Databases on consumers and their characteristics as well as data processing in digital form are becoming an important business segment for communication with end users (interactive two-way communication) and transmission of socially responsible marketing messages with emphasis on connectivity, compassion, timely and accurate information, availability (responsiveness to consumer requirements), topicality of information and more.

Only those who are flexible, agile, visible online (SEO optimization and native advertising, social media marketing), who monitor and develop their business in both real and online environment, know who and what their users want and can overcome the situation in which we currently are, hence can plan the future activities. 


\section{THE INFLUENCE OF HEALTH INFORMATION ON HEALTH CARE AWARENESS - HEALTH PREVENTION AND PROMOTION}

Health information to help consumers protect their health is more important than ever, as is developing awareness of preventative health care activities such as boosting immunity, physical activity, hand washing, keeping your distance, healthy diet, and other activities we can protect ourselves with. Self - healthy behaviour and consumer's decisions about such behaviour are influenced by information and knowledge gained by consumers through media campaigns, portals of health institutions, website koronavirus.hr and other verified sources with health-based content, in which emphasis is placed on the benefits of such behaviour or consequences of the opposite behaviour. All these activities are an incentive for a certain action, or in other words, the motivation to make a positive change in person's behaviour in order to protect themselves and others. Positive changes depend on the degree of motivation and the very understanding and processing of the message. In cases of low motivation or inability of an individual to accept the message, the peripheral way of elaboration is used, the impact of which is much smaller (Kesić, 2006, p.270).

According to the model of health assurance, it is necessary to understand the conditions necessary for a change in behaviour to occur. An individual will take measures to prevent, investigate, or control a disease or particular condition based on the following perceived factors: vulnerability, severity, benefit, barrier, action, and self-efficacy (Guzovski, 2018). Health promotion includes measures and messages of health education and upbringing aimed at health, and allows individuals and communities greater control over the factors that condition health, highlighting the positive potentials and abilities of individuals and communities to influence people's attitudes to health care and behaviour change in lifestyle. Health promotion is carried out through health actions (campaigns) that affect the spread of health messages in the community and encourage people to carry out certain health tasks (Guzovski, 2013).

The goal of marketing communication is to inform, persuade and remind, where persuasion aims to change attitudes or behaviours as a result of the action of communication appeals on the cognitive or affective part of consumer consciousness through influences via communication sources and message content. Attitudes arise as a result of the socialization of the individual where the concepts are thought structures, knowledge, beliefs, values, etc. and maintain a positive or negative tendency, a feeling to take action for or against in relation to different situations or objects. The degree of emotional involvement is enhanced by emotional appeals that are processed on a general level or a holistic approach. It is feelings that play a key role in changing attitudes in certain situations. The theory of the learning process explains the influences of persuasion on the behaviour of consumers (service users) (Kesić, 2003, p.146). In the educational function, the mass media appear as an additional component of educational institutions. The messages of this communication are based on social experience interpreted in accordance with scientific achievements, i.e. the principles of moral and political practice or socio-economic heritage (Kesić, 2003, p. 20).

Disease prevention means all procedures by which the disease is prevented, i.e. it is impossible to timely identify the disease and carry out treatment that prevents death, disability, impairment and reduced quality of life. The common goal of disease prevention and health promotion is the preservation and improvement of health, which is related to positive human and life values (Bočina, 2018). 


\section{RESEARCH - THE IMPACT OF MARKETING COMMUNICATIONS AND MESSAGES OF SOCIALLY RESPONSIBLE MARKETING ON CONSUMERS}

The results of the research on the impact of marketing communication of socially responsible marketing on consumers and the change of their habits during the pandemic in the period from $15^{\text {th }}$ to $25^{\text {th }}$ of November 2020 in the Republic of Croatia on a random sample are presented in tabular and graphical form followed by interpretation of results. 76 respondents participated in the study, of which 49 were women (64\%) and 27 were men (36\%). 20 respondents (26\%) participated in the age group ranging from 20 to 30 year olds, 21 respondents $(28 \%)$ in the age group from 31 to 40 year olds, followed by 25 respondents in the age group from 41 to 50 year olds (33\%), which is also the largest number of respondents, and in the age group from 51 to 60 year olds participated 10 respondents or $13 \%$. Considering the level of education, 20 respondents $(26 \%)$ have completed secondary education (SSS), 18 respondents (24\%) have completed higher education (higher education), 25 respondents (33\%) have a university degree (VSS), and 13 respondents (17\%) have a master's degree or doctorate (M.Sc./Dr.Sc.). 52 (68\%) respondents are employed while $24(32 \%)$ respondents are unemployed. The first question in the survey questionnaire concerned the importance of socially responsible marketing information related to the safety of the respondents themselves, and others. Out of 76 respondents, 53 (or 70\%) answered that the information was important to them, while for 23 respondents (or 30\%) this information was irrelevant. Furthermore, respondents rated the impact of socially responsible marketing messages on them on a scale from 1 to 5 where 1 indicates no impact and 5 indicates a strong impact on the world and changes in behaviour. The table 1. shows that the messages had an impact on most respondents and caused the change in their behaviour, related to their safety and the safety of others in combat.

Table 1. The impact of socially responsible marketing messages on the awareness and behaviour of respondents

\begin{tabular}{|l|c|c|c|c|c|}
\hline \multicolumn{1}{|c|}{ Message } & $\mathbf{1}$ & $\mathbf{2}$ & $\mathbf{3}$ & $\mathbf{4}$ & $\mathbf{5}$ \\
\hline Stay home & $7,89 \%$ & $11,84 \%$ & $15,79 \%$ & $18,42 \%$ & $46,05 \%$ \\
\hline $\begin{array}{l}\text { Stay responsible and keep your social } \\
\text { distance }\end{array}$ & $10,53 \%$ & $13,16 \%$ & $22,37 \%$ & $27,63 \%$ & $26,32 \%$ \\
\hline $\begin{array}{l}\text { Buy from the safety (comfort) of your } \\
\text { own home }\end{array}$ & $23,68 \%$ & $17,11 \%$ & $13,16 \%$ & $19,74 \%$ & $26,32 \%$ \\
\hline Wear a protective mask & $7,89 \%$ & $10,53 \%$ & $11,84 \%$ & $30,26 \%$ & $39,47 \%$ \\
\hline Messages about proper hand washing & $3,95 \%$ & $6,58 \%$ & $14,47 \%$ & $32,89 \%$ & $42,11 \%$ \\
\hline
\end{tabular}

Source: author's work

The next questions in the questionnaire related to the change in consumer habits. $58 \%$ of respondents said they had changed their consumer habits, while $42 \%$ of respondents had not changed their consumer habits. The changed habits were related to the reduced number of shopping trips, as well as the transition to online shopping. The largest number of respondents, $42 \%$ of them go shopping once a week, and $34 \%$ three to three times a week. $20 \%$ of the other respondents go shopping every day. The structure of responses is shown in Figure 1. 
Figure 1. Frequency of shopping trips

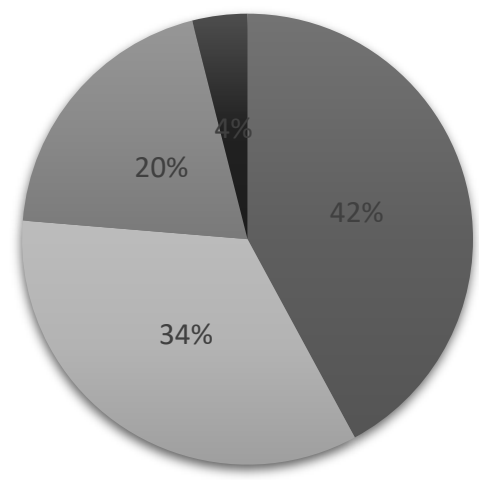

once a week

two to three times a week

on a daily basis

none of the above

Source: author's work

In addition to the reduction of shopping trips, 54\% of the respondents also started shopping online. The products they buy the most are: clothing, cosmetics, food, technical and IT equipment, furniture and other products. The structure of responses is shown in Figure 2.

Figure 2. The products that are most often purchased in the online shop

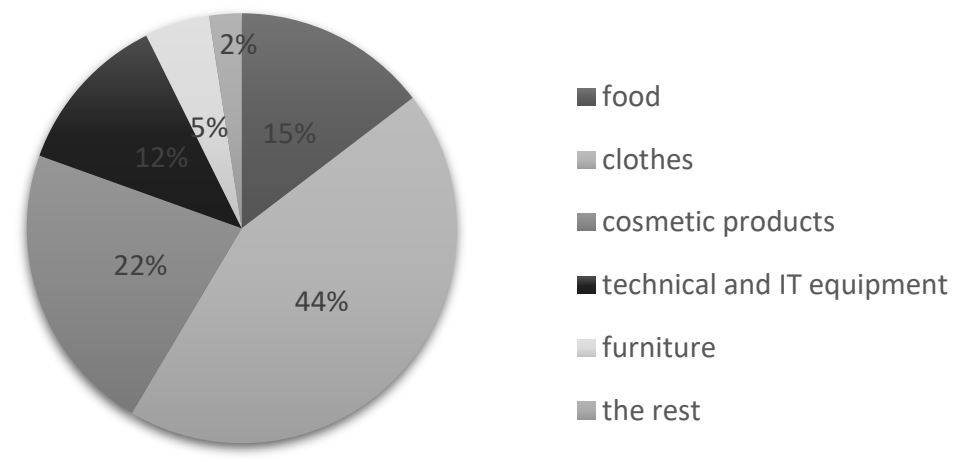

Source: author's work

Messages of socially responsible marketing influenced the change of behaviour and adoption of different consumer habits, as well as the start of online shopping for some respondents. The reasons they cited are primarily security and safety (for $54 \%$ of respondents), time save (29\%) and other reasons for $17 \%$ of respondents. The structure of responses is shown in Figure 3.

Figure 3. Reasons for online shopping

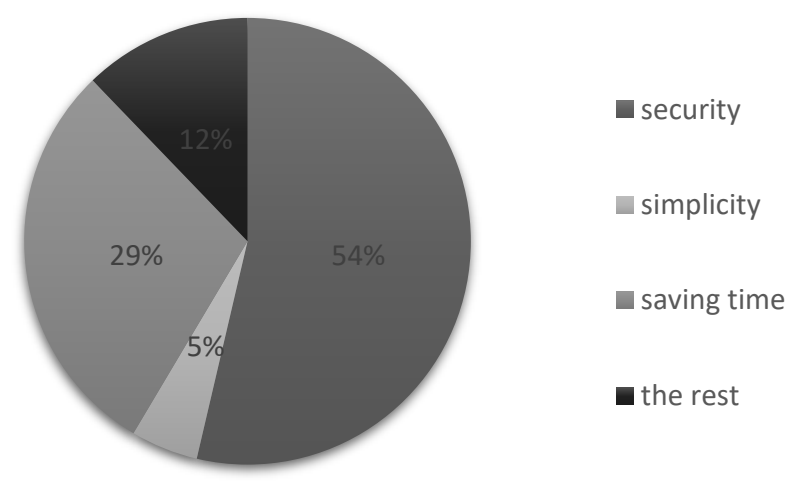

Source: author's work 
At the time of the pandemic, the most important to the respondents are health information $(30 \%)$ as well as information on the introduction of new measures and recommendations for health and safety (27\%) which are transmitted through various media. Among the media through which they receive information that is important to them, respondents state: television (26\%), the official website koronavirus.hr (21\%), social networks (17\%), websites of health institutions and public health (16\%), daily newspapers (13\%) and others (7\%).

The structure of the answers on the importance of certain information as well as the media used by the respondents are shown in Figure 4. and Figure 5.

Figure 4. Information which are subjects important during a pandemic
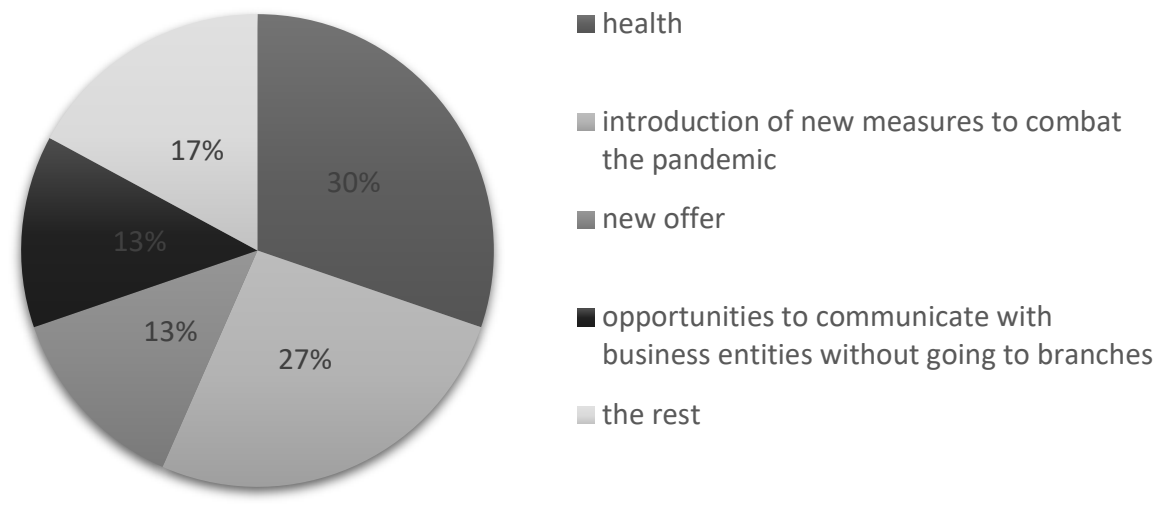

Source: author's work

Figure 5. Media for information transmission

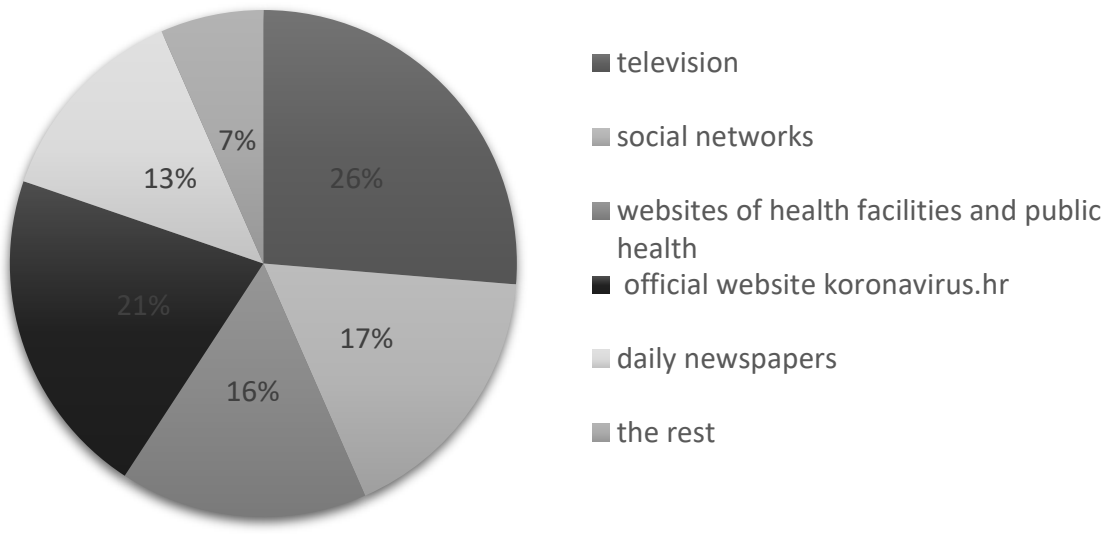

Source: author's work

\section{CONCLUSION}

The messages of socially responsible marketing seek to influence the change of behaviour and adoption of new habits as well as socially responsible behaviour of all stakeholders during the pandemic through education, informing, reminding, persuading, and taking certain actions to protect themselves and others or create safer conditions in society we live in. The research shows that the messages of socially responsible marketing such as: stay at home, stay responsible and maintain a social distance $(2 \mathrm{~m})$, wash your hands, wear protective masks, buy from the safety of your own home, etc. have influenced the change of habits for more than half of the respondents who participated in the survey, and the changes relate to the reduced number 
of shop trips as well as the more frequent use of online stores. Respondents say that the health information that is transmitted to them through various media is also very important for maintaining health and safety.

The "new normal" is becoming a normal environment for living, working, doing business where it is important to maintain health and life safety, and the changed habits we adopted in the pandemic are likely to remain in part permanent.

\section{REFERENCES}

Babić, D., \& Babić, M. (2020). Kako se sačuvati od stresa za vrijeme pandemije koronom. Zdravstveni glasnik, 6(1), 25-32 https://hrcak.srce.hr/239141

Bočina, I. Prevencija bolesti i promicanje zdravlja; Bolje spriječiti nego liječiti dostupno na http://www.zzjzpgz.hr/nzl/50/promicanje.htm (15. 12. 2018.)

Guzovski, M. (2014) Marketing pristup zdravstvu Paper presented at 4th International conference Development of public administration, April 25 and 26, 2014. College of Applied Sciences, „Lavoslav Ružička“ in Vukovar

Guzovski, M. (2018). Promjena stavova i ponašanja potrošača posredstvom integrirane marketing komunikacije Paper presented at 4th International Scientific Conference Business Conference LIMEN 2018, 13 December 2018 (pp. 450-454). Belgrade: Association of Economists and Managers of the Balkans. https://doi.org/10.31410/limen.2018.450

Kalebić Maglica, B. (2010) Teorijski pristupi u ispitivanju rizičnih zdravstvenih ponašanja, Psihologijske teme, 19(1), 71-102. https://hrcak.srce.hr/56830

Kesić, T. (2003). Integrirana marketinška komunikacija, Zagreb: Opinio d.o.o.

Kesić, T. (2006). Ponašanje Potrošača, Zagreb: Opinio d.o.o.

Kotler, P. \& Lee, N. (2011). DOP - Društveno odgovorno poslovanje: suvremena teorija $i$ najbolja praksa. 2. izd., Zagreb: M.E.P Consult.

Kotler, P. \& Lee, N. (2007). Marketing u javnom sektoru; Put do bolje izvedbe, Zagreb: Mate d.o.o.

Meler, M. (1994). Društveni marketing, Osijek, EFO.

Ozretić Došen, Đ. (2007). Osnove marketinga Zagreb: Adverta.

Smoljić, M., Guzovski, M., Rudančić, A. (2020). Važnost razvijanja digitalne marketing strategije, Paper presented at 4th International Scientific Conference Busines Conference EMAN 2020, 3 September 2020 (pp. 423-431). Belgrade: Association of Economists and Managers of the Balkans. https://doi.org/10.31410/EMAN.2020.423 